\title{
Storage of Habanero (D. rotundata) Yam ${ }^{1}$
}

\author{
Edelmiro J. Rodriguez, Orlando Parsi-Ros and Miguel A. González ${ }^{2}$
}

\section{ABSTRACT}

\begin{abstract}
Yams (Dioscorea rotundata), variety Habanero, of three harvests gathered at 30-day intervals August, September and October were stored under ambient conditions $\left(21^{\circ}\right.$ to $32^{\circ} \mathrm{C}$ and 60 to $90 \%$ relative humidity). The yams were sensory evaluated and weighed every 15 days. For sensory evaluation the yams were cut into two equal transversal portions, and in general, the bottom cuttings were found better than the top cuttings. Yams of the first harvest kept better in storage than those of the second and third harvests. All yams sprouted at about the same time. Around $50 \%$ of them sprouted between February and March, while around $90 \%$ had sprouted between March and April. All yams of the first harvest sprouted by the end of $71 / 2$ months in storage while all of the second and third harvests had sprouted by the end of 6 months. Yams of the first harvest tended to lose less weight than those of the other two harvests.
\end{abstract}

\section{INTRODUCTION}

This research was undertaken to determine the effect of storage under ambient conditions on the sensory characteristics and weight losses of Habanero yams.

Habanero yam is the variety most extensively cultivated in Puerto Rico. Commercial production of yams in Puerto Rico has been stable for the last 17 years with an average production of 280,000 cwt, but its value at farm level has increased from $\$ 1.2$ million in 1961-62 to $\$ 5.2$ million in 1977-78. In Puerto Rico this crop is planted in small farms closely following the natural period of heavy rainfall and harvested during periods of drought and short days. Consequently, there are large supplies of yams from October to January; however, because efficient storing and preservation methods are lacking, yams are very scarce from February to September.

In many tropical countries yams are stored mainly under ambient conditions or left underground until consumed (2). If left underground they are generally attacked by insects and rodents; in the other hand, if harvested they sprout after several months. Coursey (2) points out various factors causing storage losses. Among them he mentions physical and metabolic losses, and damage by insects, nematodes and microbes. Coursey (3) has also suggested that loss of moisture by desiccation of the tubers is not the only factor causing loss in weight, but that loss of solid

\footnotetext{
${ }^{1}$ Manuscript submitted to Editorial Board October 22, 1979.

${ }^{2}$ Associate Food Technologist, Research Assistant and Technical Director, respectively, Food Technology Laboratory, Agricultural Experiment Station, Mayagüez Campus, University of Puerto Rico, Río Piedras, P.R. Mrs. Isabel B. Caloni, Assistant Food Technologist, Food Technology Laboratory, conducted the sensory evaluations.
} 
matter by respiration, probably as $\mathrm{CO}_{2}$, is another important factor in weight loss.

Working with yams of the Florido (D. alata) variety, González and Collazo de Rivera (6) showed the desirability of curing them prior to storage under controlled conditions. They found that yams lost an average of $5 \%$ of their fresh weight while being cured at temperatures ranging from $29.4^{\circ}$ to $32.2^{\circ} \mathrm{C}$ and at relative humidity from 90 to $95 \%$. According to them these conditions could be attained both in controlled environmental chambers and under prevailing ambient conditions. This is very important in terms of energy conservation and of the retail price of the product, since curing in controlled environmental chambers increases the cost of the process. González and Collazo de Rivera also found that Florido yams stored under prevailing ambient conditions showed moderate weight losses which ranged from 4 to $10 \%$ until heavy sprouting took place, when losses were very high.

Rivera et al. (7) working also with yams of the Florido variety found that the dormancy period of yam can be prolonged for 4 additional months when irradiated with 7.5-Krad doses of gamma rays and stored under prevailing ambient conditions $\left(21\right.$ to $32^{\circ} \mathrm{C}$ and 60 to $95 \%$ relative humidity). They found that loss in the irradiated yams at the end of 200 days in storage was around $21 \%$ in weight, while loss in the nonirradiated yams was around $40 \%$. This technique has the disadvantage of high cost and lack of availability of gamma irradiation sources in most developing countries where yam is grown.

The use of hermetically sealed containers for storing yam tubers has also been studied, but the yams decomposed shortly after being sealed into the containers (8). On the other hand, freezing temperatures must be avoided in the storage of fresh yams because if stored under these temperatures they rot within a few days $(1,5,4)$.

Palatability of stored yams decreases sharply by the onset of sprouting. Nevertheless, González and Collazo de Rivera (6) found that, although Florido yams hardened slightly while stored at $15^{\circ} \mathrm{C}$ and $70 \%$ relative humidity, the palatability of the tubers remained high at the end of 185 storage days. Rivera et al.(7) found that no change in flavor took place during storage of irradiated yams stored under ambient conditions.

\section{MATERIALS AND METHODS}

Yams were harvested three times at 30-day intervals. The first harvest was at the beginning of yam harvesting season, August 28, 1978, and the last October 28, 1978. Yams were brought to the laboratory, washed and cured for 8 days in an ambient controlled chamber adjusted to $95^{\circ} \mathrm{F}$ $\left(33.9^{\circ} \mathrm{C}\right)$ and $95 \%$ relative humidity. They were then stored under prevailing ambient conditions $\left(21^{\circ}\right.$ to $32^{\circ} \mathrm{C}$ and 60 to $95 \%$ relative 
TABLE 1.-Sensory evaluations of yams before and after curing and during storage under ambient conditions. ${ }^{1}$

\begin{tabular}{|c|c|c|c|c|c|c|c|c|}
\hline \multirow[b]{2}{*}{ Storage periods } & \multicolumn{2}{|c|}{ Appearance } & \multicolumn{2}{|c|}{ Flavor } & \multicolumn{2}{|c|}{ Texture } & \multicolumn{2}{|c|}{ Overall Acceptability } \\
\hline & $\begin{array}{l}\text { Top } \\
\text { cuttings }\end{array}$ & $\begin{array}{l}\text { Bottom } \\
\text { cuttings }\end{array}$ & $\begin{array}{l}\text { Top } \\
\text { cuttings }\end{array}$ & $\begin{array}{l}\text { Bottom } \\
\text { cuttings }\end{array}$ & $\begin{array}{l}\text { Top } \\
\text { cuttings }\end{array}$ & $\begin{array}{l}\text { Bottom } \\
\text { cuttings }\end{array}$ & $\begin{array}{l}\text { Top } \\
\text { cuttings }\end{array}$ & $\begin{array}{l}\text { Bottom } \\
\text { cuttings }\end{array}$ \\
\hline Days & \multicolumn{8}{|c|}{ First harvest } \\
\hline Before curing & 3.9 & 5.5 & 4.4 & 4.9 & 4.7 & 5.0 & - & - \\
\hline After curing & 3.1 & 4.0 & 4.3 & 3.7 & 4.4 & 4.7 & - & - \\
\hline 15 & 4.3 & 4.6 & 4.9 & 5.0 & 4.9 & 5.1 & 4.2 & 4.8 \\
\hline 30 & 3.4 & 4.4 & 4.1 & 4.7 & 4.9 & 4.8 & 3.8 & 4.6 \\
\hline 45 & 1.7 & 4.3 & 2.9 & 4.4 & 4.0 & 4.4 & 2.7 & 4.1 \\
\hline 60 & 4.6 & 4.0 & 4.9 & 3.8 & 5.0 & 3.8 & 4.9 & 3.9 \\
\hline 75 & 4.4 & 4.2 & 4.6 & 4.2 & 4.9 & 4.6 & 4.6 & 4.0 \\
\hline 90 & 3.9 & 4.9 & 4.1 & 4.8 & 4.6 & 5.0 & 4.1 & 4.6 \\
\hline 105 & 1.8 & 3.4 & 2.7 & 4.0 & 4.2 & 4.6 & 2.3 & 3.9 \\
\hline 120 & 2.6 & 2.1 & 4.6 & 3.6 & 4.6 & 4.6 & 4.1 & 3.1 \\
\hline 135 & 4.6 & 2.3 & 3.6 & 3.3 & 4.8 & 4.2 & 3.9 & 3.0 \\
\hline 150 & 2.0 & 2.0 & 2.4 & 3.5 & 4.2 & 4.6 & 2.2 & 3.2 \\
\hline 165 & 3.8 & 4.4 & 4.4 & 3.5 & 4.6 & 4.8 & 4.2 & 3.4 \\
\hline 180 & 4.4 & 4.5 & 3.3 & 3.7 & 4.5 & 4.6 & 3.3 & 3.6 \\
\hline 195 & - & - & - & - & - & - & - & - \\
\hline \multirow[t]{2}{*}{210} & 2.1 & 3.8 & 2.8 & 3.6 & 3.8 & 3.5 & 2.6 & 3.5 \\
\hline & \multicolumn{8}{|c|}{ Second harvest } \\
\hline Before curing & 3.6 & 4.9 & 3.9 & 3.5 & 4.9 & 4.8 & 4.1 & 4.9 \\
\hline After curing & 3.8 & 5.3 & 4.9 & 5.2 & 5.1 & 5.0 & 4.2 & 5.1 \\
\hline 15 & 4.2 & 3.4 & 4.2 & 4.3 & 4.4 & 4.4 & 4.2 & 4.2 \\
\hline 30 & 5.0 & 4.3 & 4.7 & 3.8 & 4.9 & 4.6 & 4.6 & 4.1 \\
\hline 45 & 1.8 & 3.0 & 3.4 & 4.4 & 3.8 & 4.6 & 2.8 & 3.8 \\
\hline 60 & 3.4 & 4.9 & 4.8 & 5.2 & 4.9 & 5.3 & 4.9 & 5.2 \\
\hline 75 & 2.4 & 3.3 & 3.7 & 4.6 & 4.6 & 4.8 & 3.6 & 4.3 \\
\hline 90 & 4.6 & 5.4 & 4.9 & 4.9 & 4.7 & 5.0 & 4.7 & 5.0 \\
\hline
\end{tabular}




\begin{tabular}{|c|c|c|c|c|c|c|c|c|}
\hline 105 & 3.7 & 3.8 & 4.0 & 3.8 & 4.3 & 4.5 & 3.5 & 3.7 \\
\hline 120 & 2.7 & 4.1 & 2.2 & 4.1 & 4.0 & 4.6 & 1.1 & 4.2 \\
\hline 135 & 2.3 & 4.7 & 2.3 & 4.2 & 3.8 & 4.7 & 2.3 & 4.1 \\
\hline \multirow[t]{2}{*}{150} & 1.6 & 3.1 & 1.3 & 3.4 & 3.1 & 3.7 & 1.7 & 3.2 \\
\hline & \multicolumn{8}{|c|}{ Third harwes } \\
\hline Before curing & 3.9 & 4.8 & 3.5 & 5.2 & 4.7 & 4.9 & 3.7 & 5.1 \\
\hline After curing & 4.5 & 5.1 & 4.9 & 5.1 & 49 & 5.0 & 4.7 & 5.0 \\
\hline I5 & 1.4 & 3.9 & 2.9 & 4.6 & 3.8 & 4.8 & 2.0 & 4.5 \\
\hline 30 & 1.8 & 4.3 & 3.5 & 4.5 & 3.2 & 4.0 & 3.0 & 4.4 \\
\hline 45 & 3.0 & 4.5 & 4.1 & 4.6 & 3.4 & 3.9 & 3.4 & 4.4 \\
\hline 60 & 1.6 & 4.1 & 4.0 & 4.1 & 4.4 & 4.3 & 3.0 & 3.8 \\
\hline 75 & 2.2 & 4.5 & 4.2 & 4.3 & 4.2 & 4.4 & 3.1 & 4.2 \\
\hline 90 & 4.1 & 4.9 & 4.2 & 4.7 & 4.6 & 4.6 & 3.9 & 4.6 \\
\hline 105 & 4.0 & 4.5 & 4.9 & 4.1 & 4.9 & 4.2 & 4.6 & 3.0 \\
\hline 120 & 2.9 & 4.8 & 3.9 & 4.6 & 4.5 & 4.7 & 3.5 & 4.6 \\
\hline 135 & 2.7 & 3.8 & 3.1 & 4.3 & 3.7 & 4.3 & 2.8 & 4.0 \\
\hline
\end{tabular}

'A 6-point hedonic scale ranging from "like very much" (6 points) to "dislike" (1 point). 
humidity) in a well ventilated wooden storage house protected with metal screens to prevent insect damage.

Yams were weighed and submitted every 15 days to sensory evaluation during the storage period. Sensory evaluations were based on a 6-point hedonic scale ranging from "like very much" to "dislike". Samples were evaluated for appearance, flavor, mouth feel (texture), and overall acceptability. They were cut and about one inch from each end of the yam was discarded. They were then divided into two equal portions, cut transversally through the middle. These two portions, the bottom cutting (portion farther from the stem) and the top portion (portion nearest to the stem) were boiled in salt water in different pans and submitted to the panel of tasters for evaluation.

\section{RESULTS AND DISCUSSION}

Yams of the first and second harvests were completely healthy when gathered and brought to the laboratory, but yams of the third harvest had been attacked by insects and nematodes. Nonetheless, they were brought to the laboratory and submitted to all tests that were performed on the yams of the first two harvests.

Table 1 shows the results of the sensory evaluation. Yams of the first harvest were submitted to sensory evaluation for a longer period of time (210 days) because yams of the other two harvests sooner became completely unfit to be submitted to the sensory panel. Aside from sprouting, which contributed to unfitness, yam roots rotted. Rotting started spreading gradually from the outer part of the pulp toward the center. Yams of the second harvest became unfit to taste after 150 days, while yams of the third harvest became unfit after 135 days. Although not submitted to sensory evaluations, the rotten yams were weighed for an additional period of time.

There was no significant difference between top and bottom cuttings regarding overall acceptability of yams of the first harvest. The average score for these samples was between "like moderately" (4 points) and "neither like nor dislike" (3 points). However, for yams of the second and third harvests, tasters found that bottom cuttings were significantly better than top cuttings. Top cuttings were found between "like moderately" and "neither like nor dislike" while bottom cuttings were found between "like" (5 points) and "like moderately".

In relation to the appearance, there was no significant difference between the top and bottom cuttings of yams of the first harvest. Nevertheless, differences were highly significant in yams of the second and third harvests. Panelists found bottom cuttings better. Top cuttings were light yellow or cream before boiling, while bottom cuttings were 
white. Top cuttings became brown, black, or dark yellow while boiling, and sometimes the bottom cuttings became grayish.

Flavor of the top and bottom cuttings were not significantly different for yams of the first and second harvests, while for yams of the third harvest bottom cuttings were better than the top cuttings at the 5\% probability level. Sometimes both portions were bitter, with bitterness higher in the top cuttings.

Texture of top and bottom cuttings was not found significantly different

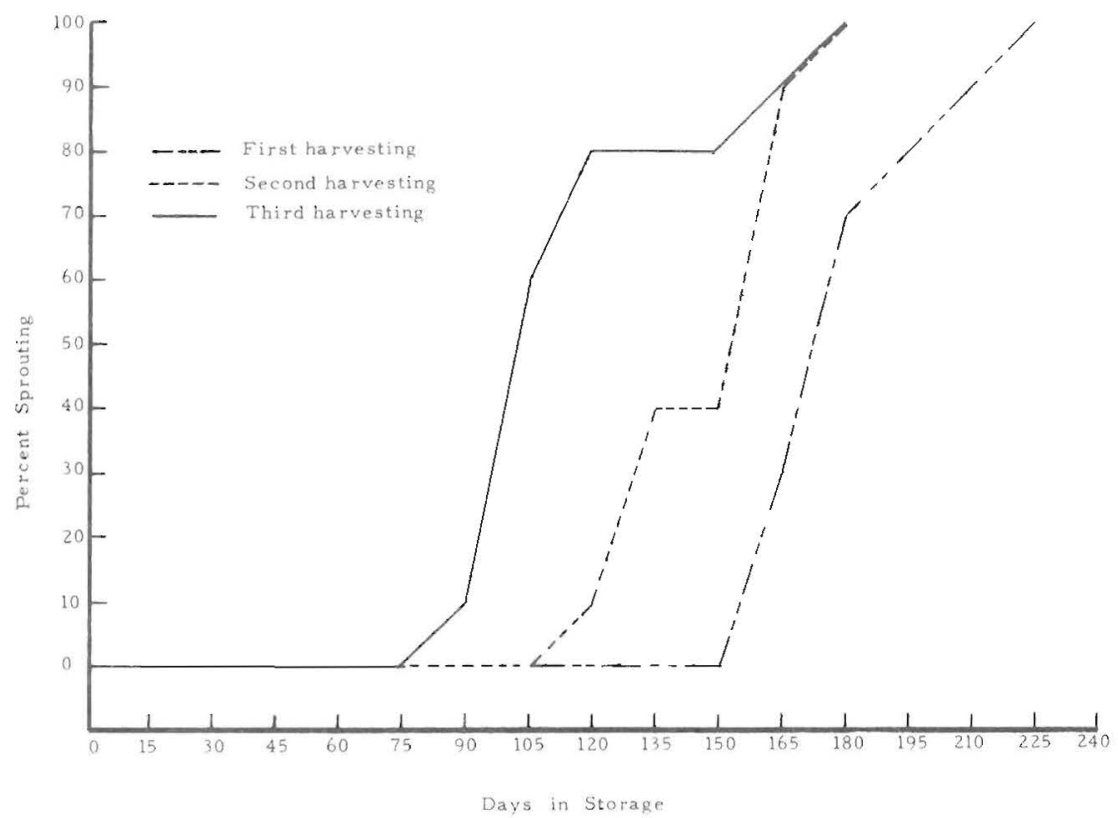

FIG. 1.-Sprouting of Habanero (D. rotundata) yams stored under ambient conditions.

for yams of the first and third harvests, whereas it was found different at the $5 \%$ level for yams of the second harvest. The average texture score for all samples was between "like" and "like moderately."

Figure 1 shows sprouting percentage of yams during storage. All samples started to sprout somewhere between January and Feburary. Yams of the first harvest began to sprout somewhere after 5 months in storage and by mid-February $30 \%$ had sprouted. Yams of the second harvest started to sprout somewhere after $31 / 2$ months in storage, while yams of the third harvest started to sprout somewhere after $2 \frac{1}{2}$ months in storage. Ten percentage of yams of the second and third harvests had sprouted by the end of 4 and 3 months in storage, respectively. Around 
$50 \%$ of yams of all harvests had sprouted between February and March, while $90 \%$ had sprouted between March and April. By May all yams had sprouted. Yams of the first harvest lasted $71 / 2$ months in storage before $100 \%$ sprouted, while those of the second and third harvest lasted 6 months.

Figure 2 shows the weight loss of Habanero yams during storage under ambient conditions. Except for the first 45 days in storage, at any given time, weight loss was higher in samples of the third harvest than in those of the first and second harvests. Yams of the second harvest tended to lose more weight than samples of the first harvest.

Storing of yams under ambient conditions is the cheapest way to store

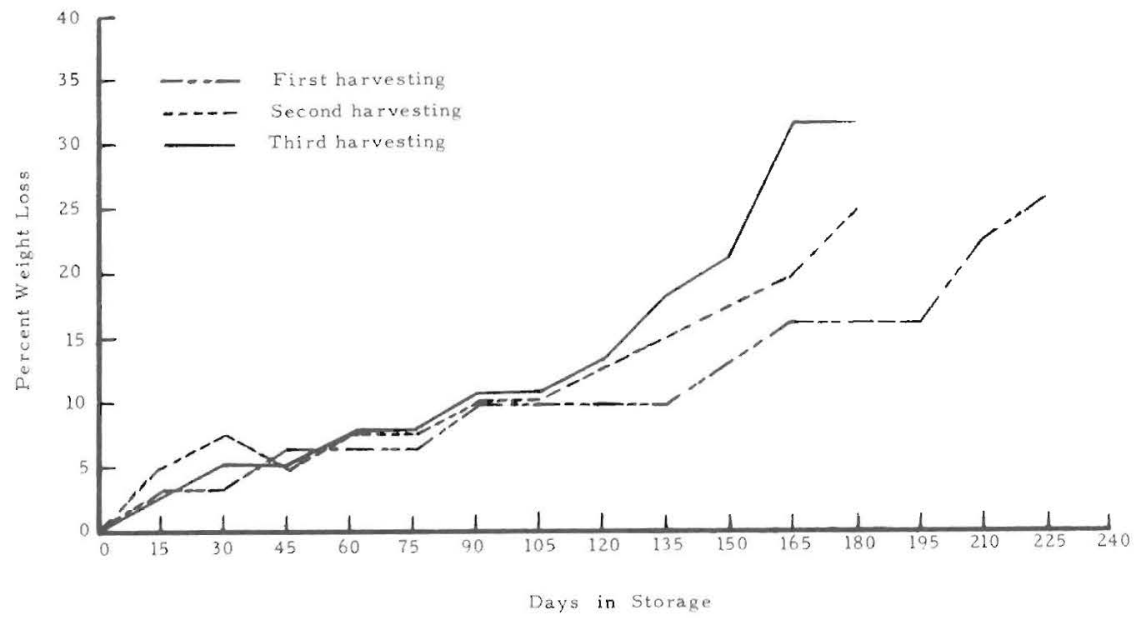

FIG. 2.-Percent weight loss of Habanero (D. rotundata) yams stored under ambient conditions.

them from the energetic standpoint. Habanero yams to be stored under ambient conditions should be harvested at an early stage of maturity to avoid damage to the root due to insects, nematodes, rodents and other pests. At this early stage of maturity, yams lose less weight in storage than those harvested at later stages, and at the same time they are edible.

\section{RESUMEN}

Se efectuaron tres cosechas de ñame (D. rotundata), variedad Habanero, a intervalo de 30 dias en los meses de agosto, septiembre y octubre, y se almacenaron en condiciones ambientales en una caseta protegida con tela metálica para evitar la entrada de insectos. Estos se pesaron y se cataron cada 15 días. Los ñames de la primera cosecha duraron más tiempo en almacén antes de deteriorarse que los de la 
segunda y tercera cosechas, en ese orden. Para las catas, los ñames se cortaron transversalmente en dos porciones iguales y se hirvieron separadamente en agua de sal. Generalmente, la porción apical fue la que tuvo más aceptación. Todos los ñames retoñaron más o menos al mismo tiempo. Por lo tanto, la época de cosecha no es un factor determinante. Cerca del $50 \%$ de todos los ñames retonaron entre febrero y marzo, mientras que alrededor del $90 \%$ retonaron entre marzo y abril. Los ñames de la primera cosecha duraron en almacén 7 1 1 2 meses antes de que el $100 \%$ retoñaran, mientras que los de la segunda y tercera cosechas duraro8 6 meses. La pérdida de peso de los ñames tuvo una tendencia a ser mayor (excepto en los primeros 45 días de almacenamiento) en los ñames de la tercera cosecha seguidos por los de la segunda.

\section{LITERATURE CITED}

1. Annual Report for 1937 for the Puerto Rico Experiment Station, pp, 42-9, USDA, 1937.

2. Coursey, D.G., 1967. Yam Storage. I. A review of yam storage practice and of information on storage losses, Food Stored Prod. Res., Vol. 2: 229-44.

3. _. 1961. The magnitude and origins of storage losses in Nigerian yams, J. Sci. Food Agri. 12 (8): 574-80.

4. __ 1968. Low temperature injury in yams, J. Food Technol. 3 (2): 14.3-50.

5. Czyhrinciw, N. and Joffe, W., 1951. Modificaciones quimicas durante la cunservación de raices y tubérculos, Arch. Venez. Nutr., 2: 49-67.

6. González, M.A. and Collazo de Rivera, A., 1972. Storage of fresh yams (Dioscorea alata L.) under controlled conditions, J. Agri. Univ. P.R., 56 (1): 46-56.

7. Rivera, J.R., González, M.A. and Cuevas Ruiz, J., 1974. Sprout inhibition of yam by gamma irradiation, J. Agri. Univ. P, R., 58 (3): 330-7.

8. Walker, H.M., 1962. The sealed storage of yams, Ann. Rep. W. Afri. Stored Prod. Res. Unit 1961, 103-6. 